Board of Governors of the Federal Reserve System

International Finance Discussion Papers

Number 468

May 1994

\title{
EUROPEAN MONETARY ARRANGEMENTS: IMPLICATIONS FOR THE DOLLAR, EXCHANGE RATE VARIABILITY AND CREDIBILITY
}

\author{
Hali J. Edison and Linda S. Kole
}

NOTE: International Finance Discussion Papers are preliminary materials circulated to stimulate discussion and critical comment. References in publications to International Finance Discussion Papers (other than an acknowledgement that the writer has had access to unpublished material) should be cleared with the author or authors. 


\begin{abstract}
$\underline{\text { Abstract }}$
This paper uses the recent history of the ERM to gain insights into what might happen to exchange rates on the road to EMU. To do this, the paper examines the variability of exchange rates, the transmission of monetary policy between countries, the role of the dollar in ERM exchange rate crises, and ERM members' credibility as measured by the realignment probabilities prior to the September 1992 crisis. We find that behavior of exchange rates has changed over: time and differs between ERM and non-ERM currencies. We identify two factors that rnight have contributed to the September 1992 crisis: high German interest rates and weakness of the U.S. dollar.
\end{abstract}




\title{
European Monetary Arrangements: Implications for the Dollar, Exchange Rate Variability and Credibility
}

\author{
Hali J. Edison and Linda S. Kole ${ }^{1}$
}

\section{Introduction}

In the autumn of 1992, the exchange rate mechanism (ERM) of the European Monetary System (EMS) began to be plagued by recurrent speculative attacks. The exchange rate crises that ensued forced some members out of the ERM (the United Kingdom and Italy), led several to devalue their central parities (Spain and Portugal) and eventually culminated in a systemwide restructuring in August 1993. At that time, European finance ministers and central bank governors agreed to temporarily widen the margins around ERM central rates from 2-1/4 to 15 percent for all ERM cross rates except the German mark/Dutch guilder rate. What sparked the series of crises that eventually forced the breakdown of the previously stable exchange rate system? Was tight German monetary policy to blame? Did the U.S. dollar play a role? This paper attempts to address these questions to gain insight into the causes of E:RM instability. A better understanding of the exchange market crises of the past may provicle some guidance as to what to expect in the transition period as the European Community moves towards European Economic and Monetary Union (EMU).

The ERM crises of 1992-1993 were so dramatic because they were preceded by a rare period of stability. Since January 1987, there have been no realignments between the core

\footnotetext{
${ }^{1}$ The authors are economists in the Division of International Finance, Board of Governors of the Federal Reserve System. We would like to thank Matthew Canzoneri, Frank Diebold, Neil Ericsson, Karen Johnson, William Helkie, Michael Klein, Andrew Levin, Lisa Lynch, Doug McManus, William Melick, Lars Svensson, Ken West, ard the participants of the Division of International Finance Workshop. We would also like to acknowledge Amy McCarthy for her work on building the crošs-country database and Alex Zarechnak for his research assistance. The views expressed in this paper are solely the responsibility of the authors and should not be interpretecl as reflecting those of the Board of Governors of the Federal Reserve System or other members of its staff.
} 
currencies. Until mid-1992, interest rate differentials between instruments denominated in ERM currencies (shown in Chart 1) narrowed substantially. The stability of the system enhanced the ability of members to gain credibility for monetary policy. The ERM continued to be remarkably stable even after most remaining capital controls were dismantled ir 1990 . By the time of the signing of the Maastricht treaty at the EC summit in December 1991, the ERM was regarded as a system of quasi-fixed exchange rates. In some sense, the very stability of the ERM in the period of 1987-1991 was one source of its breakdown in 1992. To some extent, a divergence of economic fundamentals (especially monetary policies) emerged that necessitated the exchange rate adjustments that ultimately occurred.

Denmark's rejection of the Maastricht treaty in the national referendum on June 2, 1992 increased uncertainty about the prospects for EMU and shattered the calm state of the ERM. As shown in chart 1, interest rate differentials between Germany and other ERM members began to widen, especially in those countries that were most dependent on JMU for macroeconomic policy credibility, such as Italy. Exchange market pressures mounted during the summer of 1992, and were reinforced by weakness of the U.S. dollar, which hit $a$. trough in September 1992. After the ERM crises in the fall of 1992 and early 1993, exchange market pressures abated somewhat following the French election in March 1993, and the passage of the Masstrict- "eaty (witt aral caveats) in the second Danish referendum in May 1993. However, in the summer of 1993 intense pressures in the ERM reemerged, as the deepening recession in continental Europe along with the slow pace of monetary easing by the Bundesbank put strains on other currencies in the system. 
This paper attempts to identify empirically the sources of ERM instability. The rest of the paper is organized as follows. Section II briefly describes the data. Section III examines the behavior of nominal and real exchange rates for several European countries (both ERM and non-ERM), the United States, Japan, and Canada. In particular, we evaluate differences and changes in exchange rate volatility, using short-run and long-run tests. Section IV considers the question of international transmission of monetary policy, investigating the effects of U.S. interest rates on European interest rates and the effects of German monetary policy on the rest of Europe. We demonstrate that both U.S. and German short-term interest rates influence short-term rates in other European countries. Section V studies the relationship of ERM currencies with the U.S. dollar. We provide some evidence that recent crises in the ERM were associated with dollar weakness. In Section VI, we turn our attention to credibility issues. We present estimates of devaluation expectations for seven ERM currencies relative to the German mark for the period January 1987 to May $1993 .{ }^{2}$ We also examine whether high German interest rates and changes in the U.S. dollar are determinants of those realignment expectations. The final section presents our conclusions along with some suggestions about the implications for the transition period to EMU.

\section{Description of the Data}

The major focus of this paper is on the EMS regime of fixed, but adjustable exchange rates. For the most part, the data are monthly average observations between March 1979 and May 1993. However, we also use exchange rate data from the earlier post-Bretton Woods era for some basic comparisons. Our pre-EMS sample is generally March 1973 - February 1979.

\footnotetext{
${ }^{2}$ We use shorter sample periods for the United Kingdom and Spain which joined the mechanism in October 1990 and June 1986 respectively.
} 
We examine the exchange rates between 15 currencies from countries that have been divided into four country groups: Group 1: the "core ERM" countries: Germany, France, the Netherlands, Belgium, and Denmark, Group 2: the "peripheral ERM" countries: the United Kingdom, Italy, and Spain, Group 3: other European countries: Norway, Sweden, Austria, and Switzerland, Group 4: other G-7 countries: the United States, Japan, and Canada. One might expect the countries in group 1 to be the smallest subset of EC countries that could embark on EMU perhaps initially without other EC countries such as those in group 2. Group 3 includes countries that were not members of the EC or the ERM in our sample period, but could be members of both by the time EMU occurs. Finally, group 4 includes other major players in the global financial arena.

Our empirical work below attempts to identify differences in exchange rate and interest rate behavior among these four country groups. We then focus more intensively on ERM countries, specifically on the determinants of exchange rate tensions within the ERM and the expected rate of devaluation of member currencies.

The exchange rate data represent monthly averages of daily noon quotes from the New York market. The price indices, which were used to create real exchange rates, are rnonthly consumer prices, not adjusted for seasonality. The nominal interest rates are 3 -month interbank rates.

\section{Has exchange rate behavior within ERM countries differed from that of non-ERM countries?}

The ERM was set up to limit fluctuations of participating countries' exchange rates against one another. This section examines whether the behavior of ERM exchange rates 
changed after the advent of the ERM and considers differences in the behavior of exchange rates of currencies that do not participate in the ERM. We hope to answer questions such as: Was the ERM successful at its goal of moderating exchange rate variability? If so, has the reduction of ERM exchange rate volatility influenced the volatility of non-members' exchange rates? We: also consider another breakpoint in the ERM sample period; before and after the realignment of January 1987. We address the Giavazzi and Spaventa (1990) proposition that there was a noticeable change in the behavior of ERM exchange rates, in that they became more stable after the January 1987 realignment.

Table 1 reports the variability of bilateral nominal exchange rates. Variability is defined as the standard deviation of monthly changes in the logarithm of exchange rates. ${ }^{3}$ The table reports results for the entire sample period (March 1973 - May 1993), and for four subsamples: the pre-EMS period (March 1973 - February 1979), the entire EMS period (March 1979 - May 1993), the 'soft-EMS' period (March 1979 - December 1986), and the 'hard-EMS' period (January 1987 - August 1992). The latter two subsamples are defined to distinguish between the early EMS period, when there were numerous realignments, and the later EMS period, when relative tranquility reigned.

The top panel in table I shows the variability of exchange rates against the U.S. dollar (foreign currency per U.S. dollar). One result that jumps out from the table is that the variability of the Canadian dollar was significantly lower than that of any other currency for the entire floating rate period; the variability of the Canadian dollar against the U.S. dollar

\footnotetext{
${ }^{3}$ This measure of exchange rate variability follows the literature, see for example Edison and Melvin (1990) and Ungerer et. al. (1990). See Engel and Hakkio (1993) for a discussion comparing volatility in a flexible exchange rate regime to that in a fixed, but adjustable exchange rate regime.
} 
was about 40 percent as large as the variability of the Norwegian kroner, which was the next lowest. ${ }^{4}$ Over the entire sample the German mark/dollar exchange rate displayed roughly the same variability as the Japanese yen/dollar exchange rate.

Columns 2 and 3 show that exchange rate variability against the U.S. dollar increased slightly after the inception of the EMS; with the exception of Canadian dollar volatility which did not change. There is no evidence that the ERM served to anchor the value of the mark, at least against the dollar. Columns 4 and 5 present statistics for the soft-EMS and the hard-EMS periods. ${ }^{5}$ The data suggest that there was no perceptible change in exchange rate variability between these two periods. This evidence suggests that even if intra-EFM exchange rates became more stable, this effect did not spillover to dollar exchange rates. This result also indicates that efforts at international policy coordination that intensified in the latter half of the 1980s have not helped to reduce exchange rate. variability, at least: vis-a-vis the dollar. Table 2 presents standard F-tests measuring whether volatility has changed over time. The upper panel reports results for the bilateral dollar exchange rates. . The results confirm that the volatility of dollar rates has not changed with the start of the EMS or between the soft- and hard- EMS periods.

The pattern of volatility of exchange rates against the German mark, is quite: different from that of the dollar exchange rates. These results are reported in the lower panel of table

\footnotetext{
4Te low variability of Canada's exchange rate against the dollar reflects that this exchange ratie often has: been targeted by Canadian monetary authorities during this period. The Norwegian kroner participated in the Snake during the 1970s and then was pegged to a basket of currencies including the dollar until 1990, and then to an EMS basket until 1992.

5 The 'hard' EMS period also corresponds to the post-Louvre period, a period in which the dollar was to be stabilized.
} 
1. Throughout the floating rate period the standard deviations of monthly percentage changes for the Dutch guilder and the Austrian schilling are the lowest. Unlike variability in the dollar bilateral exchange rates, variability of ERM members' exchange rates against the mark decreased after the start of the EMS as indicated by the decline in standard deviations between the second and third columns. The last two columns show that exchange rate volatility also declined over the EMS period. The lower panel of table 2 presents tests of equality of variances, which are statistically significant, indicating that the variance of exchange rates changed between these two periods. The reduction of volatility in intra-ERM exchange rates can be explained in part by the policies followed by EMS countries, in particular, the interest rate and/or intervention policies pursued by their central banks. ${ }^{6}$

The combined findings of table 1 and 2 are that the volatility of ERM members' DM exchange rates fell after the start of the EMS. In contrast, the volatility of non-ERM members' IMM exchange rates did not change significantly, with the exception of the Swiss franc. Although greater stability prevailed among ERM currencies, there was no decline in dollar exchange rate volatility: Chart 2 further illustrates the differences in volatility between dollar bilateral exchange rates and mark bilateral exchange rates. The upper panel plots the level and the rate of change of the French franc/U.S. dollar exchange rate. There is no easily identifiable change in the pattern of monthly changes during the 1973-1993 period. In contrast, the lower panel shows that monthly changes of the French franc/German mark exchange rate dampened after the inception of the EMS.

\footnotetext{
${ }^{6}$ While a study of exchange market intervention is beyond the scope of this paper, we analyze the linkages between ERM interest rates in the next section. See Edison (1993) and Mastropasqua et. al. (1988) for good summaries of the literature on intervention in the ERM.
} 
The above measures of volatility use month-to-month changes in the exchange rate. This measure essentially focuses on short-run phenomena. It says nothing about long-run variance or misalignment, which is of interest when assessing credibility. If one observes persistence of the exchange rate after a transitory shock, as opposed to mean reversion, then this may be a signal of potential sustainability problems that could undermine credibility. ${ }^{7}$ To examine the question of exchange rate persistence, we examine the time series properties of nominal and real exchange rates for a range of countries over different time periods. The objective is to test for mean reversion and for changes in exchange rate behavior civer different sample periods.

The tendency for fundamental misalignments, defined as substantial and persistent deviations of exchange rates from their equilibrium level, to arise within a group cif exchange rates can be of great economic significance (Williamson 1985). There is little question that the rise and fall of the U.S. dollar in the 1980s forced firms in the U.S. traded-goods sector to bear sizable adjustment costs. Likewise, it is possible that a shock as large and as unique as German unification caused a fundamental misalignment of the mark that precipitated the ERM crises of recent years. The desire to avoid future episodes of exchange rate misalignment and the associated economic consequences is one of the driving forces behind EMU.

Because no statistical measure of equilibrium exchange rates has been broadly agreed upon, the assessment of misalignment or long-term variability is based on unit root tests. The idea is that real exchange rates should be mean reverting. In other words, a temporary

\footnotetext{
${ }^{7}$ See for example Artis and Taylor (1993) and von Hagen and Neumann(1992).
} 
disturbance which leads to an initial over- or under- valuation of the currency will in the long run eliminate itself.

It is well-known that nominal exchange rates tend to follow a random walk, or that they contain a unit root. An important issue is whether EMS exchange rates follow random walks or whether the ERM mechanism introduces mean reversion. To examine the long-run time series properties of both nominal and real exchange rates we test whether they contain unit roots. ${ }^{8}$ For an arbitrary time series $\left(\mathrm{x}_{\mathrm{t}}\right)$, consider the model

$$
x_{t}=\beta_{0}+\beta_{1} t+\beta_{2} x_{(t-1)}+u_{t}
$$

Using this equation, we test the null hypothesis $H_{0}:\left(\beta_{0}, \beta_{1}, \beta_{2}\right)=\left(\beta_{0}, \beta_{1}, 1\right)$ against a general alternative based on a 't' statistic. All tests reported are augmented Dickey-Fuller tests. ${ }^{9}$ The null hypothesis is that the time series $x_{t}$ has a unit root; if the null hypothesis is rejected then mean reversion is suggested.

Takle 3 reports unit root tests for nominal and real exchange rates in terms of the dollar. Thi results of these tests show that it is not possible to reject the null of a unit root for all the exchange rates (real and nominal) examined over all the time periods. There are several exceptions: chiefly for both nominal and real exchange rates in Norway, Sweden and Austria before the EMS started. We performed the same tests on first differences of these time series, and in every case it was possible to reject soundly the null that these differenced

\footnotetext{
${ }^{8}$ We define the real exchange rate as $\mathrm{r}=\mathrm{e}+\mathrm{p}^{*}-\mathrm{p}$, where e is the foreign currency per U.S: dollar exchange rate, $\mathrm{p}^{*}$ is the foreign consumer price level, and $\mathrm{p}$ is the domestic consumer price level all in log terms. An increase in $r$ represents a real depreciation.

${ }^{9}$ In tables 3 - 5, we report augmented Dickey-Fuller tests where only one lag was used. The criterion for number of lags used was based upon obtaining white noise errors, which we test using an LM test.
} 
time series had unit roots. For sake of brevity, we do not report these statistics. All of these results confirm that nominal exchange rates have unit roots. The finding that real exchange rates have a unit root is much more controversial, since it implies that PPP did n.ot hold. ${ }^{10}$

Table 4 reports similar unit root test for nominal and real exchange rates against the German mark. The results are remarkably similar for most of the currencies over all the three sample periods. For ERM nominal exchange rates, we reject the unit root hypothesis : for three periods for the Dutch exchange rates, for the Belgium franc and the Italian lira during the pre-EMS period and the U.K. pound for EMS and the entire sample. ${ }^{11}$ The results for the Dutch guilder are not surprising as the guilder has moved very little against the mark. For real exchange rates, we can reject a unit root in several instances: the Dutch guilder for all periods, and the Danish kroner, the Italian lira, the Swiss franc and the Japanese yen for the entire sample period. ${ }^{12}$

The methodology described above applies conventional unit root tests without considering the effects of realignments. Edison and Fisher (1991) point out that ignoring realignments for ERM currencies leads to the finding that ERM exchange rates are well characterized by random walks. Mizrach (1993a) incorporates regime change dummy variables at each realignment in the EMS and finds that he can reject the unit root hypothesis.

\footnotetext{
${ }^{10}$ See Edison and Klovland (1987), Abuaf and Jorion (1990), Mark (1990), Patel (1990), Diebold, Husted, and Rush (1991), and Edison and Fisher (1991). on testing real exchange rates and PPP. See Edison, Gagnon, and Melick (1994) on problems of testing for PPP using small samples.

${ }^{11}$ Some of these rejections are due to the fact that we have standardised our reporting of resu ts by using only one-lag in the augmented Dickey-Fuller tests. If we include the appropriate number of lags, then we find fewer rejections.

${ }^{12}$ These results are consistent with the findings of Edison and Fisher (1991) and Nieuwland, Verschoor, and Wolff (1991).
} 
Following this reasoning, we examine the statistical properties of the ERM currencies within the bands. In particular, we examine the statistical properties of the deviation of ERM members' DM exchange rates from their DM central rates. Table 5 reports unit root tests of deviations of the $\log$ of the spot exchange rate from the log of the central parity. The results of this test show that the deviation of exchange rates within the band are mean reverting, that is, we reject the null hypothesis of a unit root. Chart 3 plots the path of the actual and central French franc/German mark exchange rate as well as the deviation of that rate from its central rate. The chart clearly illustrates our unit root results: the time series properties of the deviation cf the exchange rate from its central rates appears to be stationary. This characteristic of exchange rate behavior will be used in our assessment of credibility in section V1. But first let us turn to two related issues: the transmission of interest rate changes between the United States, Germany, and other ERM countries and the relationship between the U.S. dollar and intra-ERM exchange rate variability.

\section{International Transmission of Monetary Policy}

The decline in the volatility of EMS exchange rates since the establishment of the ERM leads us to examine international linkages between interest rates. Our hypothesis is that German interest rates have had an important influence on rates in other ERM members during the EMS period. We also investigate whether there has been feedback from interest rate innovations in major ERM countries such as France to German short-term interest rates. A better understanding of the relationship between different countries' interest rates within the ERM may shed some light on the recent currency crises. Since unification, Germany has maintained relatively high interest rates to combat inflationary pressures. It has been argued 
that high German interest rates may have been the dominant factor behind the ERM currency crises (see Gardner and Perraudin (1992)).

Many authors have characterized the ERM as a currency block dominated by German monetary policy. Giavazzi and Giovannini (1989) and Giavazzi and Pagano (1988) have suggested that the ERM was anchored by the German mark, because the Bundesbank had high credibility due to its strong commitment to maintaining low inflation. ${ }^{13}$ The empirical literature has not been able to substantiate convincingly German monetary dominance. These tests generally have been based on 'Granger' causality, testing the influences of German monetary policy on other ERM countries' monetary policy and vice versa.

In order to gauge the effects of German interest rates on those in the rest of Europe, we control for the influence of U.S. monetary policy on European interest rates. By including U.S. short-term interest rates in the analysis, we avoid finding a spurious correlation between ERM interest rates that is driven by common correlations with U.S. interest rates. Also, the role of U.S. interest rates in determining other countries' interest rates may give us an idea of what effects an EC wide interest rate could have once EMU takes place.

We begin by considering the statistical properties of interest rates and interest rate differentials. ${ }^{14}$ Table 6 presents unit root tests similar to those used in section III. The first column reports unit root tests on 3-month nominal interest rates in the major ERM participants, Japan, Canada, and the United States. The sample period is limited to the EMS

\footnotetext{
${ }^{13}$ See Wyplosz (1989) for an alternative explanation.
}

${ }^{14}$ See also Frankel et. al. (1992) for an analysis of statistical properties of inters rates across ERIM countries. 
time period of March 1979 to May 1993. The results indicate that we cannot reject the null hypothesis of a unit root for all interest rates.

Column 2 reports unit root tests on interest rate differentials between the U.S. 3-month rate and 3-month rates in the other countries. The results of these tests are mixed. The null hypothesis of a unit root for interest rate differentials with U.S. rates is rejected for 5 of the 7 pairs: the exceptions are Germany and the Netherlands. In those instances where we reject the null hypothesis, the results suggest that there might be a long-run relationship between these variables. That is, there is some evidence of cointegration between U.S. 3-month interest rates and 3-month rates in France. Belgium, Denmark, Japan, and Canada. ${ }^{15}$ This suggests that these countries ${ }^{\circ}$ interest rates are linked with U.S. interest rates. The apparent lack of stationarity of the German-U.S. interest rate differential is consistent with German monetary authorities having relatively more autonomy than other ERM countries.

In contrast, for the unit root tests on interest rate differentials with Germany, shown in column 3, we cannot reject the null for 5 of the 7 pairs: the exceptions are the Netherlands and Denmark. As is well known, Dutch monetary policy has closely emulated German monetary policy during most of this sample period; therefore, it is not surprising that Dutch and German 3-month rates appear to be cointegrated. What is a puzzle is why the French and Belgium interest differentials with U.S. rates seem more stationary than those vis-a-vis

\footnotetext{
is We do not pursue this line of investigation further as there are more powerful cointegration tests; see Kremers, Ericsson, and Dolado (1992).
} 
Germany. These seemingly counterintuitive findings are similar to those reported by

Katsimbris and Miller (1993). ${ }^{16}$

To take a first pass at the issue of the transmission of monetary policy between these countries, we perform Granger causality tests on changes in short term interest rates. Of course, several caveats about the following analysis must be borne in mind. Granger causality tests cannot reveal the true nature of a causal relationship, and even if they could, changes in 3-month interest rate are associated with other factors than monetary policy. Nevertheless, we use short-term interest rates as the best available indicator of morietary policy.

First, we test the influence of U.S. short-term interest rates on other countries' shortterm interest rates by regressing changes of country j's 3-month rate on its own past values and the contemporaneous and past changes of U.S. interest rates. ${ }^{17}$ The regressior.s are based on:

$$
\Delta i^{j}=\sum_{k=1}^{n=5} \alpha_{k} \Delta i_{t-k}^{j}+\sum_{k=0}^{n=5} \beta_{k} \Delta i_{t-k}^{u s}
$$

Panel A of table 7 reports the likelihood ratio test of the joint significance of contemporaneous and lagged changes in U.S. interest rates. It shows that in 5 of the 7

\footnotetext{
${ }^{16}$ These results may be due to a change in the relationship. For example, France and Belgium may have geared their monetary policies more toward U.S. monetary policy in the soft-EMS period, yet closer oriented to German policy in the hard-EMS period. Alternatively, currency realignments may be contributing to these results.

17 The inclusion of contemporaneous changes in U.S. interest rates means the test is not strictly a Granger causality test, which would include only lagged changes in U.S. rates. For purposes of this analysis, we include the contemporaneous level because we use monthly, rather than daily or weekly data. It is likely tinat in many instances, the foreign response to a change in U.S. monetary policy would occur within the same month, so that Granger causality tests on monthly data would be unable to detect the relationship. Note we assume that the U.S. interest rate is exogenous in interpretation of these equations.
} 
countries we reject the null hypothesis that U.S. interest rates do not significantly affect other countries interest rates: the exceptions being Japan and Denmark.

To test the influence of German monetary policy, we add to equation (2) contemporaneous and past changes in German interest rates. The test of the significance of German interest rates is conditional on the U.S. effects. The equation used is as follows:

$$
\Delta i^{j}=\sum_{k=1}^{n=5} \alpha_{k} \Delta i_{t-k}^{j}+\sum_{k=0}^{n=5} \beta_{k} \Delta i_{t-k}^{u s}+\sum_{k=0}^{n=5} \gamma_{k} \Delta i_{t-k}^{G}
$$

Panel B of lable 7 reports these tests. The first column of panel B shows that for all the European countries, German interest rates are jointly significant with U.S. rates, whereas they are not for Canada and Japan. This result suggests that German monetary policy has an independent influence on other European countries. Von Hagen and Fratianni (1990) interpret this result as indicating European monetary policy is not independent of German monetary policy. Most of the literature on German dominance excludes the contemporaneous changes in interest rates and uses only lagged interest rates. ${ }^{18}$ The results of those tests, reported in the second column of panel, are similar to those in the first column. The only exception is for Canada, for which the coefficient on German interest rates become significant when one drops contemporaneous changes in U.S. interest rates. We also tested the effects of German 3-month rates on the U.S. 3-month rate, using the same method. The results indicated that the coefficients on all German interest rates were jointly significant.

Next we consider the effects of changes in various ERM countries' interest rates on changes in German interest rates to see whether German monetary policy is interdependent or

\footnotetext{
${ }^{18}$ See for example De Grauwe (1989) and von Hagen and Fratianni (1990) In contrast, Weber (I990) uses contemporaneous and lagged values..
} 
insular. These results, once again. are conditional on the inclusion of U.S. interest rates. The specification is as follows:

$$
\Delta i^{g}=\sum_{k=1}^{n=5} \alpha_{k} \Delta i_{t-k}^{g}+\sum_{k=0}^{n=5} \beta_{k} \Delta i_{t-k}^{u s}+\sum_{k=0}^{n=5} \gamma_{k} \Delta i_{t-k}^{J}
$$

The results, shown in panel $\mathrm{C}$, are mixed. Interest rates changes in France and the Netherlands are jointly significant in the determination of German short-term rates when using contemporaneous and lagged values.

The two conclusions that emerge from table 7 are that: (1) U.S. 3-month interest rates had a strong influence on 3-month rates in most of the other countries in our sample indicating that U.S. monetary policy is transmitted abroad, (2) in addition to U.S. inte:rest rates, German short-term rates are important in the determination of interest rates in other ERM countries, and (3) short-term rates in some of the other ERM countries affect German short term rates.

\section{What is the relationship of ERM currencies with the U.S. dollar?}

It has often been noted that there is a systematic relationship between fluctuations in ERM exchange rates and changes in the U.S dollar. ${ }^{19}$ In particular, when the dollar is strong in foreign exchange markets, the mark tends to be weak vis-a-vis other European currencies. ${ }^{20}$ Some dollar crises have been associated with EMS instability. Giavazzi and Giovannini

\footnotetext{
19 Ungerer et al (1990) pointed that the dollar's strength during the early years of the EMS may have stabilized exchange rates in the ERM.

21) Giavazzi and Giovannini (1989) found this empirical regularity to be consistent with a dynamic inodel of portfolio allocation in which assets were imperfect substitutes. However, for the ERM currencies, this effect was more pronounced in the pre-EMS period than in the $1979-1987$ period. They also found that capital controls played a role.
} 
(1989) pointed out an interesting regularity: All but one EMS realignment between 1979 and 1987 took place after a fall in the dollar and were followed by a dollar recovery. ${ }^{21}$ The ERM crises of autumn 1992 mirrored this pattern. The Federal Reserve Board (FRB) trade-weighted value of the dollar reached its yearly low on September 2 nd just days before the ERM crises ensued. This section examines the comovement of changes in German mark/dollar exchange rates with changes in German mark/ERM bilateral exchange rates. In particular, it investigates whether the data on exchange rate changes suggests that fluctuations in the dollar are associated with fluctuations of bilateral ERM exchange rates. We contrast the movernents of seven ERM currencies (French franc, Dutch guilder, Belgium franc, Danish kroner, British pound sterling, Italian lira, and Spanish peseta) with movements of four nonERM European currencies (Norwegian kroner, Swedish kroner, Austrian schilling, and the Swiss franc), and the Japanese yen and the Canadian dollar.

Chart 4 plots two separate episodes of dollar weakness that coincided with strains in the ERM. The top panel illustrates the relationship of the FRB trade-weighted value of the dollar and the French franc/German mark from February 1, 1983 to March 20, 1983. Immediately prior to the March 20th ERM realignment, there were two episodes of dollar weakness. The first episode started in mid-February and ended several days later. At that time there was little movement of the franc/mark rate. The second episode of U.S. dollar weakness, which was less dramatic and included a partial recovery, was followed by a realignment. The bottom panel shows Italian lira/German mark prior to the September 1992

\footnotetext{
${ }^{21}$ The February 22, 1982 realignment of the Belgian franc and the Danish kroner were not associated with this pattern of behavior for the dollar.
} 
crisis. At roughly the time the dollar weakens, the lira/mark rate rises towards the upper band limit, indicating the potential strain in the system. ${ }^{22}$

Table 8 reports estimates of simple correlations of percent changes (first differences of natural logarithms) in bilateral rates vis-a-vis the mark and the percent change in the DM/dollar exchange rate. The sample spans the period June 1973 to May 1993 and is; divided into seven samples: the entire sample, the years preceding the EMS, the entire EMS period, the soft-EMS period, the hard-EMS period, and two periods of dollar depreciation (against the DM) during the EMS: March 1985 - July 1985 and September 1989 - February 1991. A negative correlation, for example, indicates that a given currency tended to depreciate relative to the DM when the DM appreciated relative to the dollar. If a currency was perfectly pegged to the dollar, then one would expect this correlation to be -1 . One extreme example of such a relationship is the Canadian dollar; for Canada, the correlation coefficient is close to negative one indicating that the Canadian dollar is closely tied to the U.S. dollar. Another less extreme example is the cell for the French franc, which is -1J.3 indicating that a decline in the $\mathrm{DM} /$ dollar rate is on average associated with an increase (or depreciation) of the franc against the DM.

In general, table 8 shows that ERM currencies tend to weaken vis-a-vis the DM when the dollar is weak. In contrast, some of the non-ERM currencies do not follow this pattern. For example, the DM exchange rates of the Swiss franc (during the EMS period) and the Austrian schilling (during the soft-EMS period) show some positive correlation with the $\mathrm{DM} / \$$ rate: these currencies appreciated relative to the DM when the dollar fell.

\footnotetext{
${ }^{22}$ Chart 4 plots the bilateral band limits of $+/-2.25$ percent. Quite often the effective limits are quite different from this range, because it is dependent upon all the participating currencies.
} 
There are not only large differences between countries in response to changes in the dollar exchange rate, but also the correlations have changed over time. The table indicates that a break may have occurred after the EMS started. For all of the currencies in the table, the correlation was more negative in the pre-EMS period (shown in the second column) than in the whole sample or the EMS period (in the third column). ${ }^{23}$ For the ERM currencies, the finding that the correlations are larger prior to the EMS than during the EMS suggests that ERM cross: rates were more stable after the EMS was initiated. This result is stronger for the ERM member countries, but is also observed for the remaining currencies examined, with the exception of the Canadian dollar. The deepening and increased integration of international financial markets between the 1970s and the 1980s may be one factor behind this result. Another important factor is probably the dismantling of international capital controls that took place durirg the sample period. The lower correlations seen in the hard-EMS vs. the softEMS in the United Kingdom, Italy, and Spain could stem in part from the removal of capital controbls.

The final two columns present the correlations for the two weak dollar periods. It appears the. the second episode, from autumn 1989 to winter 1991, was associated with more strains within the ERM, than the first episode, March to July 1985 in the soft-EMS period. In contrast for the peripheral ERM currencies such as the pound and the peseta, the first episode, before these currencies had joined the ERM, was associated with greater negative correlation. The correlation between movements in the dollar and movements in ERM cross rates poses the risk that an episode of dollar weakness could impair credibility in the ERM on

\footnotetext{
${ }^{23}$ This replicates the findings of Giavazzi and Giovannini (1989).
} 
the path to EMU.

\section{Credibility and the ERM crises of September 1992 and August 1993}

Credibility of the ERM will be crucial during the transition to EMU. If the ERM is not able to reestablish some semblance of its former credibility, exchange rate crises may occur in the years preceding Stage 3. Because the convergence criteria require that no realignment take place within two years of the start of Stage 3, recurrent exchange rate crises could delay the start of EMU. In addition, it is likely that even once EMU is complete, the credibility of the newly vested European central bank (ECB) will depend on the credibility of the ERM in the transition to EMU. An analysis of the recent ERM crises may give us an idea of what to watch for on the way to EMU. In this section, we consider whether there was an observable drop in credibility that would have helped to predict ERM crises.

To investigate the issue of time-varying credibility, we estimated devaluation expectations for seven ERM currencies relative to the DM for the period January $19: 37$ to September $1992 .^{24}$ For the core-ERM group, we extend the sample to July 1993 . W'e employ the drift-adjustment technique described in Rose and Svensson (1993) and Svensson (1993) to estimate the expectation of a currency realignment. ${ }^{25}$ This drift-adjustment method adjusts interest rate differentials by the expected rate of depreciation within the band. The estimation is straightforward as the expected rates of depreciation within the bands are done by simple linear regression.

\footnotetext{
${ }^{24}$ Spain and the United Kingdom joined the ERM in June 1989 and October 1990, respectively and therefore, we begin their samples then.

${ }^{25}$ For additional applications of this method see Frankel and Phillips (1992), Kole (1992), Lysebo and Mundaca (1992), and Mizrach (1993b,c). Chen and Giovannini (1993) apply a related method to model devaluation expectations.
} 
Let $\delta_{\mathrm{t}}^{\tau} \equiv \mathrm{i}_{\mathrm{t}}^{\tau}-\mathrm{i}_{\mathrm{t}}^{\tau^{*}}$ denote the domestic currency's interest rate differential at time $\mathrm{t}$, the difference between the domestic currency interest rate on a bond with maturity of $\tau$ years, $i_{t}^{\tau}$, and a foreign (German) interest rate $i_{t}^{\tau^{*}}$. Let $s_{t}$ be the log exchange rate, here in terms of domestic surrency per DM, so that $s_{t+k}-s_{t}$ represents the rate of depreciation between time $t$ and $\mathrm{t}+\mathrm{k}$. The uncovered interest parity can be written as: ${ }^{26}$

$$
\delta_{t}^{\tau}=E_{t}\left[\Delta s_{t+\tau}\right] / \tau
$$

where $E_{t}$ denotes expectations conditional upon information available at time t. Equation (5) states that the interest rate differential equals the expected rate of depreciation of the domestic currency :elative to the DM during the time interval of the corresponding maturity, which in our empirical work is equal to 3 months. The assumption of uncovered interest parity is not a bad approximation when the foreign exchange risk premium is small, a condition that Svensson (1992) argued is likely to hold in target zones, even when there is some risk of devaluation.

The exchange rate can be decomposed into two elements:

$$
s_{t}=c_{t}+x_{t}
$$

where $c_{t}: s$ the official central parity at time $t$ and $x_{t}$ is the deviation of the exchange rate from the central rate, or the movement of the exchange rate within its EMS band. Between realignments, all variation in $s_{t}$ stems from variation in $x_{t}$. The following analysis focuses on the expected rate of realignment, $\mathrm{E} \Delta \mathrm{c} / \tau$, rather than the absolute size of realignment:

\footnotetext{
${ }^{26}$ Note that we use the approximation $\ln (1+i) \approx i_{t}$ here and in the empirical work.
} 


$$
E_{t} \Delta c_{t+\tau} / \tau=E_{t} \Delta s_{t+\tau} / \tau-E_{t} \Delta x_{t+\tau} / \tau
$$

Equation (7) states that the expected rate of realignment equals the expected (total) rate of exchange rate change minus the expected rate of depreciation within the band.

Equation (7) can be rewritten as equation (8) using the definition of uncovered interest rate parity in equation (5).

$$
E_{t} \Delta c_{t+\tau} / \tau=\delta_{t}^{\tau}-E_{t} \Delta x_{t+\tau} / \tau
$$

Equation (8) states that the expected rate of realignment can be measured as the interest rate differential minus the expected rate of depreciation within the band. If the target zorie is perfectly credible $\mathrm{E}_{\mathrm{t}} \Delta \mathrm{c}_{\mathrm{t}+\tau}=0$, then $\delta_{\mathrm{t}}^{\tau}=\mathrm{E}_{\mathrm{t}} \Delta \mathrm{x}_{\mathrm{t}+\tau} / \tau$. Because credibility is less than perfect, $E_{t} \Delta c_{t+\tau}$ is likely to have been positive for most ERM currencies' DM exchange rates, indicating that some amount of devaluation was expected during the EMS period. The hypothesis that EMS credibility increased until early 1992 would be reflected by $E_{t}\left\llcorner c_{t+\tau}\right.$ gradually approaching 0 . Similarly, the loss of credibility around the time of the Danish rejection of Maastricht would have increased $E_{t} \Delta c_{t+\tau}$.

As Bertola and Svensson (1993) point out, it is sufficient to find an estimate of $\mathrm{E}_{\mathrm{t}} \Delta \mathrm{x}_{\mathrm{t}+\tau} / \tau$ and subtract that estimate from the interest rate differential to estimate the expected rate of realignment, $\mathrm{E}_{\mathrm{t}} \Delta \mathrm{c}_{\mathrm{t}+\tau} / \tau$. However the estimation of the expected rate of depreciation within the band is complicated by the fact that the exchange rate within the band usually jumps at realignments. In order to account for this possibility the expected change of the exchange rate within the band is expanded to:

$$
E_{t}\left[\Delta x_{t+\tau}\right]=\left(1-p_{t}^{\tau}\right) E_{t}\left[\Delta x_{t+\tau} \mid \text { no realignment }\right]+p_{t}^{\tau} E_{t}\left[\Delta x_{t+\tau} \mid \text { realignment }\right]
$$


where $p_{t}^{\tau}$ is the expected probability at time $t$ that a realignment will take place over the time covered by maturity $\tau$. By substituting (9) into (8) we arrive at the following expression for the expected rate of devaluation, $\mathrm{g}_{\mathrm{t}}^{\tau}$ :

$$
\begin{gathered}
g_{t}^{\tau}=E_{t}\left[\Delta c_{t+\tau}\right] / \tau+p_{t}^{\tau}\left(E_{t}\left[\Delta x_{t+\tau} \mid \text { realignment }\right]-E_{t}\left[\Delta x_{t+\tau} \mid \text { no realignment }\right]\right) / \tau= \\
\delta_{t}^{\tau}-E_{t}\left[\Delta x_{t+\tau} \mid \text { no realignment }\right] / \tau
\end{gathered}
$$

The index of credibility, $\mathrm{g}_{\mathrm{t}}^{\tau}$, is no longer the expected rate of change of the central parity, but the expected rate of change of the exchange rate as a whole, which includes the expected drift within the E:RM bands as well as the expected rate of a realignment. Rose and Svensson refer to the left hand side term as the expected rate of devaluation, the expected effect on the exchange rate of expected changes in the exchange rate band.

To construct an estimate of the expected rate of devaluation, first we estimate the expected rate of depreciation within the band. Bertola and Svensson (1993) show that a linear approximation may be acceptable and use the current level of the exchange rate within the band as the single determinant of the expected future rate of depreciation within the band. In subsequent work, Lindberg et al. (1991) and Rose and Svensson (1993) and Svensson (1993) consider a number of different functional forms and explanatory variables. We use a simple linear regression and follow Svensson by including domestic and German interest rates in all regressions. We make one slight modification to the regressions: we add the change in the $\log$ of tine DM/dollar exchange rate to each regression. As discussed in the previous section, it has often been cited that strains within the ERM are most likely to occur when the dollar is weak. Therefore, we added this variable to test whether changes in the dollar have influenced movements of exchange rates within the band. 
The regression we use takes the form:

$$
\Delta x_{t+\tau}=\alpha_{0}+\alpha_{1} x_{t}+\alpha_{2} i_{t}+\alpha_{3} i_{t}^{*}+\alpha_{4} \Delta D M \$+\epsilon_{t}
$$

where DM\$ is the mark/dollar bilateral exchange rate. This regression is run separately for seven DM exchange rates (French franc, Dutch guilder, Belgium franc, Danish kroner, British pound sterling, Italian lira and Spanish peseta). We use monthly data and 3-month interest rates. $^{27}$ The equation is estimated by Ordinary Least Squares (OLS) for the period January 1987 to May 1993 for the first four countries and to August 1992 for the last three countries with start dates varying depending on the dates the currency began participating in the ERM. The estimation is complicated by the fact that there are overlapping observations, therefore we compute the standard errors using a Newey-West correction allowing for serial correlation and heteroscedasticity.

Table 9 shows the estimates of equation (11). The fit of the equations is not very good. But, as Rose and Svensson have pointed out, this is not important as we are trying to measure the expected change in the exchange rate within the band, not the actual change. The coefficients on $\mathrm{x}$ are all statistically significant and less than zero, indicating that there is mean reversion in the $\mathrm{x}$ process for all seven currencies. This result is consistent with the findings reported in table 5. The coefficients on own-country interest rates are all statistically significant and negative while the coefficients on German interest rates are positive and significant in all equations except those for the United Kingdom and Italy. This sign pattern

\footnotetext{
27 This implies that $\tau=1 / 4$, or that the maturity is a quarter of a year. We use this conventior, rather than a monthly one, because interest rates are usually quoted at an annual rate.
} 
on the interest rate coefficients is consistent with a domestic currency interest rate smoothing policy as discussed in Svensson (1992).

The coefficient on the change in the DM/\$ exchange rate is statistically significant for Denmark, Spain, and the United Kingdom. The sign on the coefficients for Spain and the United Kingdom is consistent with the notion that as the DM appreciates against the dollar, there may be strain in the EMS. The coefficient on the Danish kroner does not follow this pattern.

According to equation (10), the expected rates of devaluation can be estimated by subtracting the estimate of the expected rate of depreciation within the band from the corresponding interest rate differential. Charts 5 - 11 contain the time series graphs of these estimates of expected devaluation. A positive (negative) value indicates expectations of a devaluation (revaluation) of the currency against the DM. The units of the vertical axis, the measure of the expected realignment is percent per annum, and is the product of the size and the frequency of the realignment.

Most of these plots show that the ERM lacked perfect credibility even during the tranquil period. There are two exceptions. As one would expect, these exceptions are the Netherlands and Belgium, where expected devaluation appears to have been close to zero. In contrast, in France and Denmark after the Maastricht treaty was rejected we measure an increase in expectations of a devaluation. For those countries that actually did devalue in the autumn of 1992, the pattern differs somewhat. We find that there are increasing signs of devaluation for Italy and Spain, whereas in the United Kingdom, after the general election in April 199:? there were no signs of devaluation until August, but then expectations rose 
dramatically. (This is consistent with our finding that the dollar mattered, especially' in the cases of the British pound and the Italian lira.)

What is the source of these expectations of devaluation? Following Rose and Svensson (1993b), we investigate the determinates of our derived devaluation expectations. The purpose is to determine whether there is a link between these variables and our devaluation expectations. Here we limit our investigation to two explanatory factor: the change in the log of the DM/\$ exchange rate as a measure of dollar strain in the EMS and each country's interest rate differential with Germany.

Table 10 reports the regressions of the devaluation expectations, $g$, on the changes in the DM/dollar rate and interest rate differentials. Changes in the dollar appear to be weakly linked to expectations of a realignment. The only exception is for the British pound, where the coefficient is positive and statistically significant, indicating that the pourd moves closely with the dollar. We also find that increases in ERM interest rate differentials are correlated with higher realignment expectations. Note that the results reported here need to be interpreted carefully, as we have not taken account of the problems of generated regressors or of overlapping data problems.

\section{Concluding Remarks}

In this paper, we use the recent history of the ERM to gain insights into what might happen to exchange rates on the road to EMU. We show that short-run volatility of ERM exchange rates against the mark fell after the start of the EMS, while there was no noticeable changes in volatility of exchange rates vis-a-vis the U.S. dollar. Therefore, it appears that the ERM reduced exchange rate volatility among member currencies without changing exchange 
rate volatility against non-members. This result suggests that the volatility of non-members' exchange rates need not be affected by volatility of intra-ERM exchange rates during the transition to $\mathrm{EMU}^{28}$

We also show that the long-run behavior of both real and nominal exchange rates against both the U.S. dollar and the DM display non-stationary behavior, suggesting that a transitory shock generates persistence rather than mean reverting behavior. However, if one accounts for changes in central rates for intra-ERM exchange rates in terms of the DM we show that the deviations of exchange rates within the band are mean reverting. This result suggests that there is no tendency for fundamental misalignments of ERM currencies, after the adjustrnents to the central rate are taken into account. One conclusion that can be drawn from these results is that intra- and inter-ERM exchange rates behave differently and that the ERM has had little effect on the dollar. Conversely, we find some evidence indicating that weakness of the dollar adds strain to the ERM. The paper confirms that there is a correlation between movements in the dollar and movements in ERM cross rates. Episodes of dollar weakness seem to cause the most problems for the currencies that are less attached to the ERM (such as the pound, lira, and peseta in the autumn 1992 episode).

In the section on the international transmission of monetary policy, we demonstrate that interest rates in major industrialized countries are closely linked. We find that U.S. short-term interest rates influence short-term rates abroad. Furthermore, we find that German interest rates consistently influence other ERM countries' interest rates, and that German interest rates are also affected by other ERM countries' rates.

\footnotetext{
${ }^{28}$ See also Johnson (1993) on the implications of EMU for the U.S. dollar.
} 
To consider issues of credibility in the ERM, we estimate exchange rate realignment expectations since January 1987. We identify and examine two factors that may have contributed to the September 1992 crisis: high German interest rates and the weakness of the dollar. Our results are tentative, but they do suggest that these factors played a role. One message we take away from all this is that international linkages are important not only to the European countries, but also to the United States.

This paper suggests that during the transition to EMU, the ERM will be vulnerable to shocks that tend to significantly change the value of the U.S. dollar or German interest rates. An episode of dollar weakness could cause problems on the path to EMU. It is possible that the wider bands in the current ERM will give enough scope of maneuver to prevent :urther ERM crises, but this is by no means certain. It is also possible that pressures on the ERM will become more subdued as the European recession ends and the stance of German monetary policy becomes less of a constraint. However, the potential for speculative attacks will remain until the day Stage 3 dawns. The behavior of ERM exchange rates in cciming years will have an important influence on the speed of transition to EMU as well as the initial makeup of the new currency to be adopted. 


\section{References}

Abuaf, N. and P. Jorion, "Purchasing Power Parity in the Long Run," Journal of Finance, 45, March 1990, pp. $157-74$.

Artis, Michael J. and Mark P. Taylor, "The Stabilizing Effect of the ERM on Exchange Rates and Interest Rates: An Empirical Investigation," IMF Working Paper No. 93/67, August 1993.

Bertola, Ciiuseppe and Lars Svensson, "Stochastic Devaluation Risk and the Empirical Fit of Target Zcne Models", Review of Economic Studies, vol. 60, July 1993, pp. 689-712.

Chen, Zhiohui and Alberto Giovannini, "The Determinants of Realignment Expectations Under the EMS: Some Empirical Regularities," Working Paper No. 4291, National Bureau of Economic Research, Inc., March 1993.

De Grauve, Paul, "Is the European Monetary System a DM-Zone?" Centre for European Policy Research Discussion Paper \#297, March 1989.

Diebold, Francis X., Steven Husted, and Mark Rush, "Real Exchange Rates Under the Gold Standard," Journal of Political Economy, December 1991, 99, pp. 1252 - 1271.

Edison, Hali J., "The Effectiveness of Central-Bank Intervention: A Survey of the Literature After 1982," Special Papers in International Economics, Princeton University, No. 18, July 1993.

Edison, Hali J. and Jan T. Klovland, "A Quantitative Reassessment of the Purchasing Power Parity Hypothesis: Some Evidence on Norway and the United States, " Journal of Applied Econometrics, October 1987, 2, pp. 309 - 334.

Edison, Hali J. and Eric O'N Fisher, "A long-run view of the European Monetary System, Journal of International Money and Finance, 10 March 1991, pp. 53 - 70.

Edison, Hali J. and Michael Melvin, "The Determinants and Implications of the Choice of an Exchange Rate System," in Monetary Policy in an Era of Change, edited by Cagan, P., W. Haraf, and T. Willett, American Enterprise Institute, Washington D.C., 1990, pp 1 - 44.

Edison, Hali J., Joseph E. Gagnon, and William R. Melick, "Understanding the Empirical Literature on Purchasing Power Parity: The Post-Bretton Woods Era," International Finance Discussion Papers No.465, Board of Governors of the Federal Reserve System, April 1994.

Engel, Charles and Craig S. Hakkio, "Exchange Rate Volatility in the EMS," RWP 93-, Federal Reserve Board of Kansas City, May 1993. 
Frankel, Jeffrey and Steven Phillips, "The European Monetary System: Credible at Last?" Oxford Economic Papers, October 1992, 44, pp. 791 - 816.

Frankel, Jeffrey, Steven Phillips, and Menzie Chinn, "Financial and Currency Integration in the European Monetary System: The Statistical Record," Working Paper No. C92-005, Center for International and Development Economics Research, University of California at Eerkeley, December 1992.

Gardner, E. H., and W. R. Perraudin, "Asymmetry in the ERM: A Case Study of French and German Interest Rates Since Basle-Nybord," IMF Working Paper 92/96, November 1992.

Giavazzi, Francesco and Luigi Spaventa, "The 'New' EMS', in The European Monetiry System in the 1990s edited by P.De Grauwe and Lucas Papademos, London: Longmán, 1990.

Giavazzi, Francesco and Alberto Giovannini, Limiting Exchange Rate Flexibility: The European Monetary System, MIT Press: Cambridge, Mass. 1989.

Giavazzi, Francesco and Marco Pagano, "The Advantage of Tying One's Hands: EMS Discipline and Central Bank Credibility," European Economic Review, Vol. 32, June 1988, pp. $1055-1082$.

Johnson, Karen H., "International Dimension of European Monetary Union: Implications for the Dollar," unpublished paper, Board of Governors of the Federal Reserve System, Washington, D.C., 1993.

Katsimbris, George M. and Stephen M. Miller, "Interest Rate Linkages within the European Monetary System: Further Analysis," Journal of Money Credit and Banking, vol. 25, November 1993, pp. $771-785$.

Kole, Linda S., "The United Kingdom and the EMS: Regime Change and Credibility Gain," unpublished paper, Board of Governors of the Federal Reserve System, July 1992.

Kremers, Jeroen, J.M., Neil R. Ericsson, and Juan J. Dolado, "The Power of Cointegration Tests," Oxford Bulletin of Economics and Statistics, vol 54, August 1992, pp $325-348$..

Lindberg, Hans, Paul Soderlind and Lars E. O. Svensson, "Devaluation Expectations: The Swedish Krona 1985-92," The Economic Journal, September 1993, vol 103, pp1170 - 1179.

Lysebo, Tore Andre and B. Gabriela Mundaca, "Does the Credibility of the Exchange Rate Depend on the Width of the Target Zone?" Working Paper, Norges Bank (The Central Bank of Norway), Oslo:August 1992.

Mastropasqua, Cristina, Stefano Micossi and Roberto Rinaldi, "Interventions, Sterilisation and Monetary Policy in European Monetary System Countries, 1979 - 1987," in Francesco 
Giavazzi, Stefano Micossi, and Marcus Miller, eds., The European Monetary System: Proceedings of a Conference Organised by the Banca d'Italia, STEP, and CEPR, Cambridge and New York, Cambridge University Press, 1988, pp 252-287.

Mizrach, Bruce, "Mean Reversion in EMS Exchange Rates," Research Paper No.

9301,Federal Reserve Bank of New York, January 1993a.

Mizrach, Bruce, "The ERM Since Basle-Nyborg: Convergence, Credibility, and Crisis," Federal Resserve Bank of New York, April 1993 b.

Mizrach, Bruce, "Target Zone Models with Stochastic Realignments: An Econometric Evaluation," Federal Reserve Bank of New York, revised April 1993c.

Nieuwlanc., Fred G.M.C., Willem F.C. Verschoor, and Christian C.P. Wolff, "EMS Exchange Rates," Jolurnal of International Financial Markets, Institutions \& Money, Vol. I(2), 1991, pp. 21-40.

Patel, J. "Nests of Purchasing Power Parity as a Long-Run Relation," Journal of Applied Econometrics, October 1990, 5, pp. 367 - 380.

Rose, Andrew K. and Lars E. O. Svensson, "Expected and Predicted Realignments: The FF/DM Exchange Rate During the EMS," International Finance Discussion Papers No. 395, Board of Governors of the Federal Reserve System, April 1991.

Svensson, Lars E. O., "The Foreign Exchange Risk Premium in a Target Zone Devaluation Risk," Joumal of International Economics, Vol. 33 (August 1992), pp. 21-40.

Svensson, Lars E. O., "Assessing Target Zone Credibility: Mean Reversion and Devaluation Expectations in the ERMs, 1979-1992," European Economic Review, No. 37, Elsevier Science Publishers. North-Holland: May 1993, pp. 763-802.

Ungerer, Horst, Jouko J. Hauvonen, Augusto Lopez-Claros, and Thomas Mayer, The European Monetary System: Developments and Perspectives, International Monetary Fund Occasiona. Paper \#73, November 1990.

von Hagerı, Jurgen, and Michele Fratianni, "German dominance in the EMS: evidence from interest rates," Journal of International Money and Finance, vol 9, December 1990, pp. 358 375.

von Hager,, Jurgen, and Manfred J.M. Neumann, "Real Exchange Rates Within and Between Currency Areas: How Far Away Is EMU?" Discussion Paper No. 660, London: Centre for Economic Policy Research, June 1992. 
Weber, Axel A., "EMU and Asymmetries and Adjustment Problems in the EMS: Scme Empirical Evidence," Centre for Economic Policy Research, Discussion Paper No. 448, London:August 1990.

Williamson, John, The Exchange Rate System (revised edition), Washington, D.C.: Institute for International Economics, 1985.

Wyplosz, Charles, "Asymmetry in the EMS: Intentional or Systemic?" European Economic Review, vol. 33, March 1989, pp. 310 - 320. 


\begin{tabular}{|c|c|c|c|c|c|}
\hline \multicolumn{6}{|c|}{ (Standard Deviations of monthly log changes) } \\
\hline & $\begin{array}{c}\text { March } 1973- \\
\text { May } 1993\end{array}$ & $\begin{array}{l}\text { March } 1973- \\
\text { February } 1979\end{array}$ & $\begin{array}{c}\text { March } 1979 \text { - } \\
\text { May } 1993\end{array}$ & $\begin{array}{l}\text { March } 1979 \text { - } \\
\text { December } 1986\end{array}$ & $\begin{array}{l}\text { January } 1987 \text { - } \\
\text { August } 1992\end{array}$ \\
\hline \multicolumn{6}{|c|}{ Bilateral Kates Against $\$$} \\
\hline Germany & 2.9 & 2.8 & 2.9 & 2.9 & 2.9 \\
\hline France & 2.8 & 2.4 & 2.9 & 3.0 & 2.8 \\
\hline Netherlands & 2.8 & 2.5 & 2.9 & 2.9 & 3.0 \\
\hline Belgium & 2.8 & 2.5 & 3.0 & 3.0 & 2.9 \\
\hline Denmark & 2.8 & 2.4 & 2.9 & 2.9 & 2.9 \\
\hline UK & 2.8 & 2.1 & 3.1 & 2.7 & 3.0 \\
\hline Italy & 2.7 & 2.2 & 2.9 & 2.7 & 2.6 \\
\hline Spain & 2.7 & 2.5 & 2.7 & 2.4 & 2.7 \\
\hline Norway & 2.4 & 2.2 & 2.4 & 2.3 & 2.5 \\
\hline Sweden & 2.6 & 2.4 & 2.7 & 2.4 & 2.3 \\
\hline Austria & 2.9 & 2.7 & 3.0 & 3.0 & 3.0 \\
\hline Swiss & 3.2 & 3.0 & 3.3 & 3.3 & 3.2 \\
\hline Japan & 2.8 & 2.3 & 2.9 & 3.1 & 2.8 \\
\hline Canada & 1.0 & 1.0 & 1.0 & 1.0 & 0.9 \\
\hline \multicolumn{6}{|c|}{ Bilateral Rates Against DM } \\
\hline France & 1.2 & 1.8 & 0.7 & 0.9 & 0.4 \\
\hline Netherlands & 0.6 & 1.0 & 0.3 & 0.4 & 0.1 \\
\hline Belgium & 0.7 & 0.9 & 0.7 & 0.9 & 0.2 \\
\hline Denmark & 0.8 & 1.1 & 0.6 & 0.8 & 0.4 \\
\hline UK & 2.3 & 2.5 & 2.2 & 2.4 & 1.5 \\
\hline Italy & 1.8 & 2.7 & 1.3 & 0.9 & 0.6 \\
\hline Spain & 2.3 & 3.4 & 1.6 & 1.7 & 1.1 \\
\hline Norway & 1.4 & 1.4 & 1.3 & 1.5 & 1.0 \\
\hline Sweden & 1.8 & 1.6 & 1.9 & 2.1 & 1.0 \\
\hline Austria & 0.5 & 0.5 & 0.5 & 0.2 & 0.7 \\
\hline Swiss & 1.4 & 1.9 & 1.2 & 1.3 & 1.1 \\
\hline Japan & 2.5 & 2.6 & 2.5 & 2.5 & 2.4 \\
\hline Canada & 2.9 & 3.1 & 2.9 & 2.8 & 3.1 \\
\hline
\end{tabular}




$$
\text { - } 34 \text { - }
$$

\begin{tabular}{|c|c|c|}
\hline \multicolumn{3}{|c|}{ (* denotes significant at the 5 percent level) } \\
\hline & PreEMS/EMS & 'Soft' EMS/'Hard' EMS \\
\hline \multicolumn{3}{|c|}{ Bilateral Rates Against $\$$} \\
\hline Germany & .93 & .98 \\
\hline France & .71 & 1.2 \\
\hline Netherlands & .77 & .96 \\
\hline Belgium & .72 & 1.03 \\
\hline Denmark & .71 & .95 \\
\hline U.K. & .47 & .85 \\
\hline Italy & .61 & 1.03 \\
\hline Spain & .85 & .80 \\
\hline Norway & .85 & .81 \\
\hline Sweden & .82 & 1.2 \\
\hline Austria & .84 & .99 \\
\hline Switzerland & .87 & 1.01 \\
\hline Japan & .62 & 1.21 \\
\hline Canada & .94 & 1.05 \\
\hline \multicolumn{3}{|c|}{ Bilateral Rates Against DM } \\
\hline France & $6.59^{*}$ & $4.56^{*}$ \\
\hline Netherlands & $12.5^{*}$ & $19.3^{*}$ \\
\hline Belgium & $1.76^{*}$ & $22.43^{*}$ \\
\hline Denmark & $2.86^{*}$ & $4.58^{*}$ \\
\hline U.K. & 1.32 & $2.46^{*}$ \\
\hline Italy & $4.64^{*}$ & $2.38^{*}$ \\
\hline Spain & $4.54^{*}$ & $2.54^{*}$ \\
\hline Norway & 1.17 & $2.17^{*}$ \\
\hline Sweden & .74 & $4.59^{*}$ \\
\hline Austria & .89 & .08 \\
\hline Switzerland & $2.49^{*}$ & $1.45^{*}$ \\
\hline Japan & 1.09 & 1.14 \\
\hline Canada & 1.16 & .78 \\
\hline
\end{tabular}




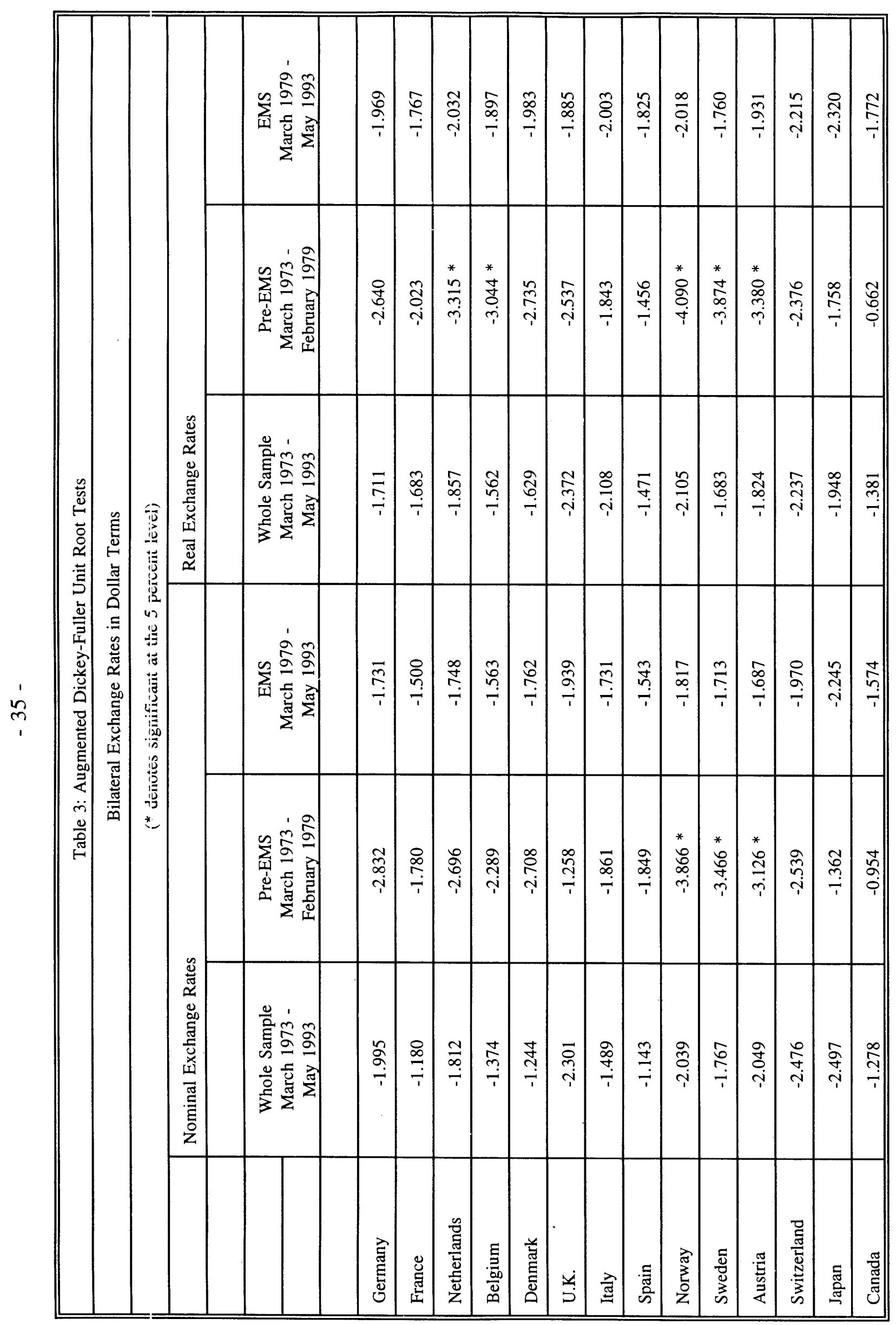




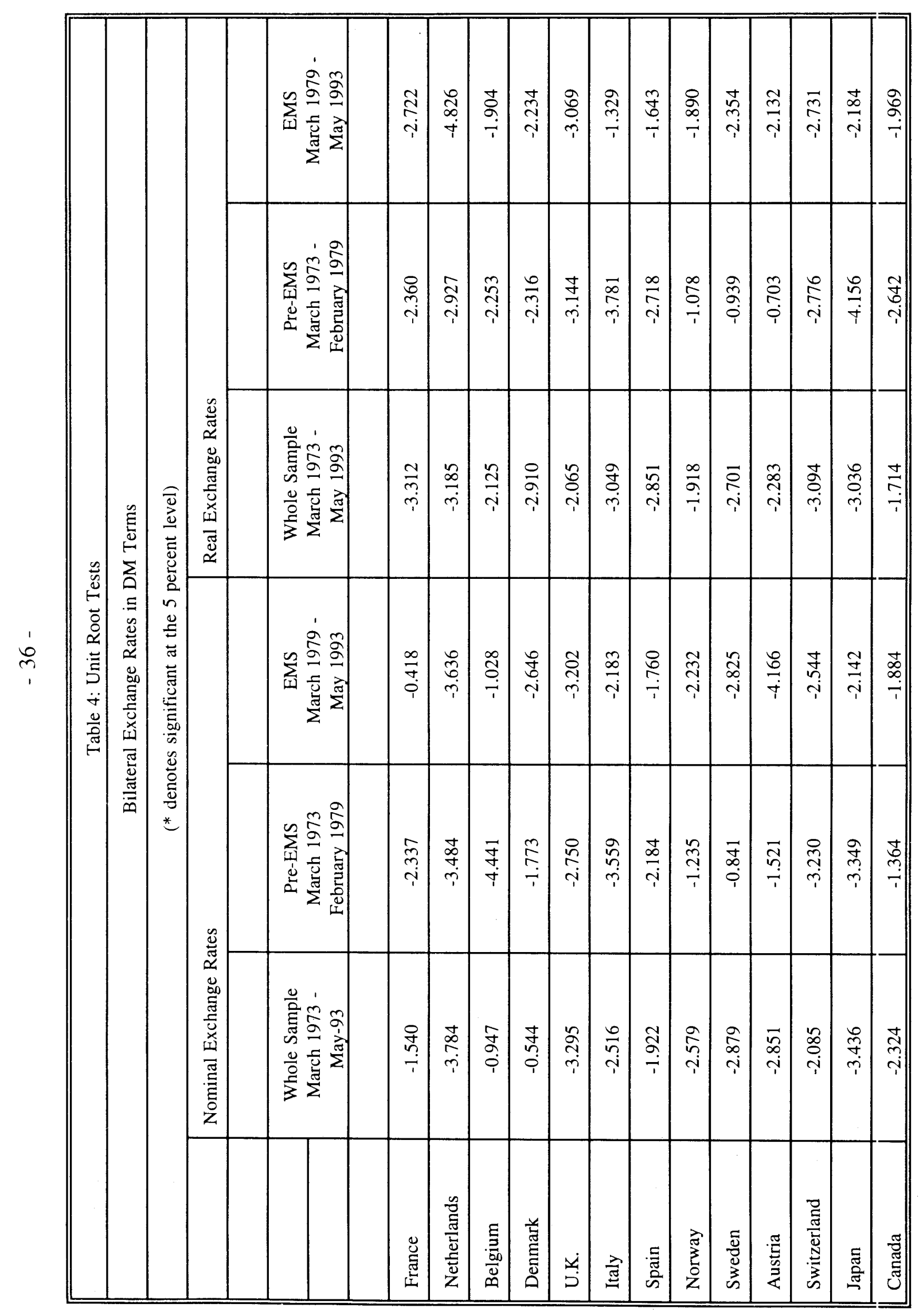




\begin{tabular}{|c|c|c|c|c|}
\hline \multicolumn{5}{|c|}{ Table 5: Unit Root Tests } \\
\hline \multicolumn{5}{|c|}{ For European Currencies less the Central Rate } \\
\hline \multicolumn{5}{|c|}{ ( $*$ denotes significant at the 5 percent level) } \\
\hline Nominal & France & Netherlands & Belgium & Denmark \\
\hline in terms of $\mathrm{DM}$ & $-5.816 *$ & $-4.724 *$ & $-5.369 *$ & $-5.611 *$ \\
\hline
\end{tabular}




\begin{tabular}{||l|l|l|l||}
\hline \multicolumn{4}{|c|}{ Table 6: Unit Root Test for Interest Rates } \\
\hline & \multicolumn{3}{|c|}{ Own March 1979 to May 1993 } \\
\hline German & $\begin{array}{l}\text { Differential } \\
\text { Against U.S. }\end{array}$ & $\begin{array}{l}\text { Differential } \\
\text { Against DM }\end{array}$ \\
\hline French & -1.64 & -2.36 & - \\
\hline Dutch & -2.22 & $-3.33^{*}$ & -2.42 \\
\hline Belgium & -1.72 & -2.45 & $-3.42^{*}$ \\
\hline Danish & -1.95 & $-4.12^{*}$ & -1.73 \\
\hline & -2.50 & $-3.68^{*}$ & $-3.15^{*}$ \\
\hline United States & & & \\
\hline Japan & -2.11 & - & -2.36 \\
\hline Canada & -1.94 & $-3.45^{*}$ & -2.29 \\
\hline \hline
\end{tabular}

Notes to table:

Unit root tests are augmented Dickey-Fuller tests with one lag and no trend term;. the critical value for 74 observations is: $28^{\prime \prime} 9$ at the 5 percent level. 


\begin{tabular}{|c|c|c|}
\hline \multicolumn{3}{|c|}{ Granger Causality Tests } \\
\hline A. From United States to & $\begin{array}{l}\text { Current and Lagged } \\
\text { Likelihood Ratio Test }\end{array}$ & $\begin{array}{l}\text { Lagged } \\
\text { Likelihood Ratio Test }\end{array}$ \\
\hline Germany & $5.6^{*}$ & $5.4^{*}$ \\
\hline France & $2.8^{*}$ & $3.2^{*}$ \\
\hline Netherlands & $8.4^{\circ}$ & $3.9^{*}$ \\
\hline Belgium & $5.9^{*}$ & $4.4^{*}$ \\
\hline Denmark & 1.9 & 1.1 \\
\hline Japan & 2.0 & 1.6 \\
\hline Canada & $17.2^{*}$ & $2.9^{*}$ \\
\hline \multicolumn{3}{|l|}{ B. From Germany to } \\
\hline France & $9.2^{*}$ & $10.5^{*}$ \\
\hline Netherlands & $19.1^{*}$ & $6.1^{*}$ \\
\hline Belgium & $8.5^{*}$ & $8.1^{*}$ \\
\hline Denmark & $3.1^{*}$ & $3.6^{*}$ \\
\hline Japan & 0.4 & 0.5 \\
\hline Canada & 2.0 & $5.1^{*}$ \\
\hline \multicolumn{3}{|l|}{ C To Germany from } \\
\hline France & $2.5^{*}$ & $3.1^{*}$ \\
\hline Netherlands & $17.3^{*}$ & $2.5^{*}$ \\
\hline Belgium & 1.1 & 0.6 \\
\hline Denmark & 1.9 & $2.7^{*}$ \\
\hline
\end{tabular}

Notes to table:

* denotes significant at the 5 percent level. 


\begin{tabular}{|c|c|c|c|c|c|c|c|}
\hline \multicolumn{8}{|c|}{ on the Expected Exchange Rate } \\
\hline & France & Netherlands & Belgium & Denmark & U.K. & Italy & Spain \\
\hline constant & $\begin{array}{l}-.002 \\
(. .004)\end{array}$ & $\begin{array}{l}.001 \\
(.001)\end{array}$ & $\begin{array}{l}.001 \\
(.001)\end{array}$ & $\begin{array}{l}.001 \\
(.004)\end{array}$ & $\begin{array}{l}-.04 \\
(.025)\end{array}$ & $\begin{array}{l}-.006 \\
(.012)\end{array}$ & $\begin{array}{l}-.04 \\
(.03)\end{array}$ \\
\hline$\Delta \mathrm{DM} \$$ & $\begin{array}{l}-.07 \\
(.07)\end{array}$ & $\begin{array}{l}-.03 \\
(.01)\end{array}$ & $\begin{array}{l}-.10 \\
(.04)\end{array}$ & $\begin{array}{l}-.08 \\
(.07)\end{array}$ & $\begin{array}{l}.64 \\
(.44)\end{array}$ & $\begin{array}{l}-.27 \\
(.15)\end{array}$ & $\begin{array}{l}.22 \\
(.33)\end{array}$ \\
\hline$i-i^{*}$ & $\begin{array}{l}1.03 \\
(.14)\end{array}$ & $\begin{array}{l}1.18 \\
(0.8)\end{array}$ & $\begin{array}{l}1.01 \\
(.11)\end{array}$ & $\begin{array}{l}.59 \\
(.11)\end{array}$ & $\begin{array}{l}2.00 \\
(.88)\end{array}$ & $\begin{array}{l}1.01 \\
(.24)\end{array}$ & $\begin{array}{l}1.64 \\
(.53)\end{array}$ \\
\hline NOBS & 74 & 74 & 74 & 74 & 20 & 65 & 36 \\
\hline $\mathrm{R}^{2}$ & .66 & .81 & .76 & .59 & .32 & .67 & .54 \\
\hline$\sigma$ & .018 & .004 & .011 & .02 & .06 & .04 & .06 \\
\hline
\end{tabular}




\section{Chart 1}

\section{Short-Term Interest Rates in ERM countries}

(Monthly)

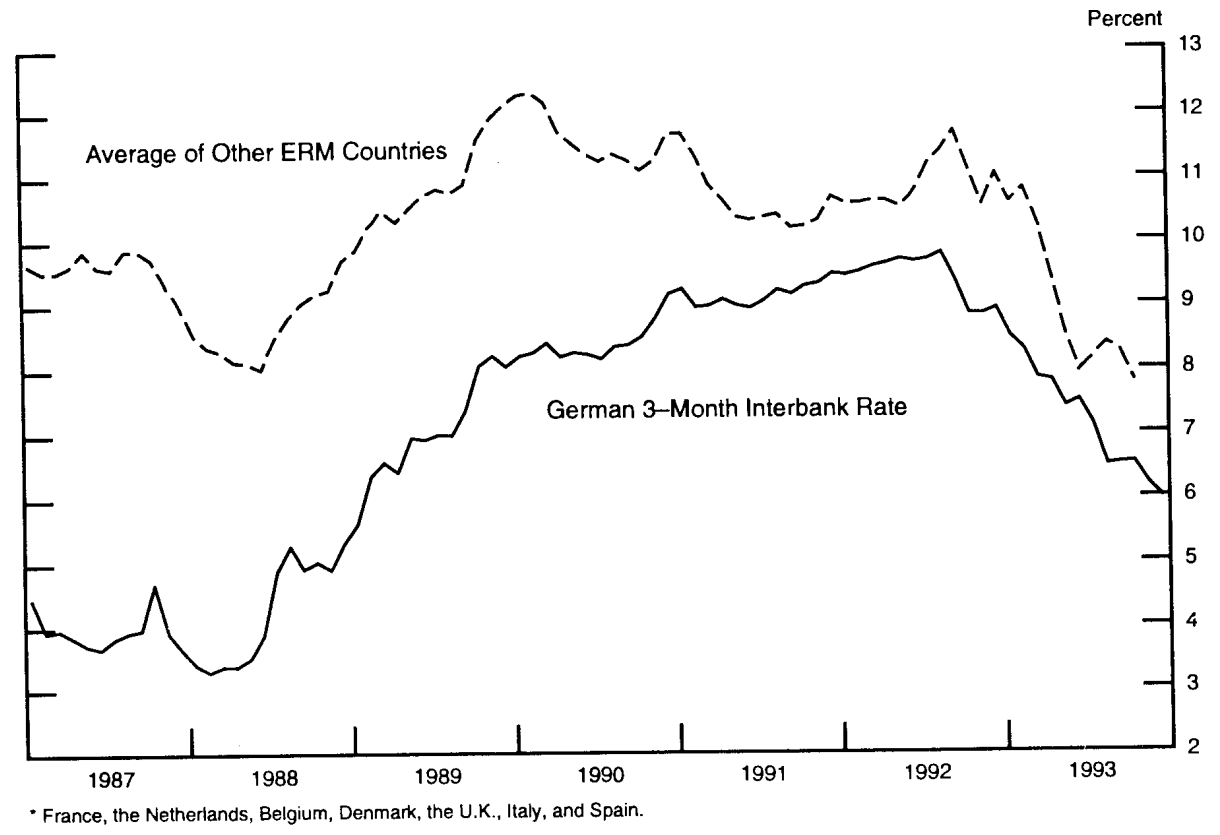




\section{Chart 2}

Bilateral Exchange Rate: Log Level and Percentage Change

$$
\text { France-U.S. }
$$
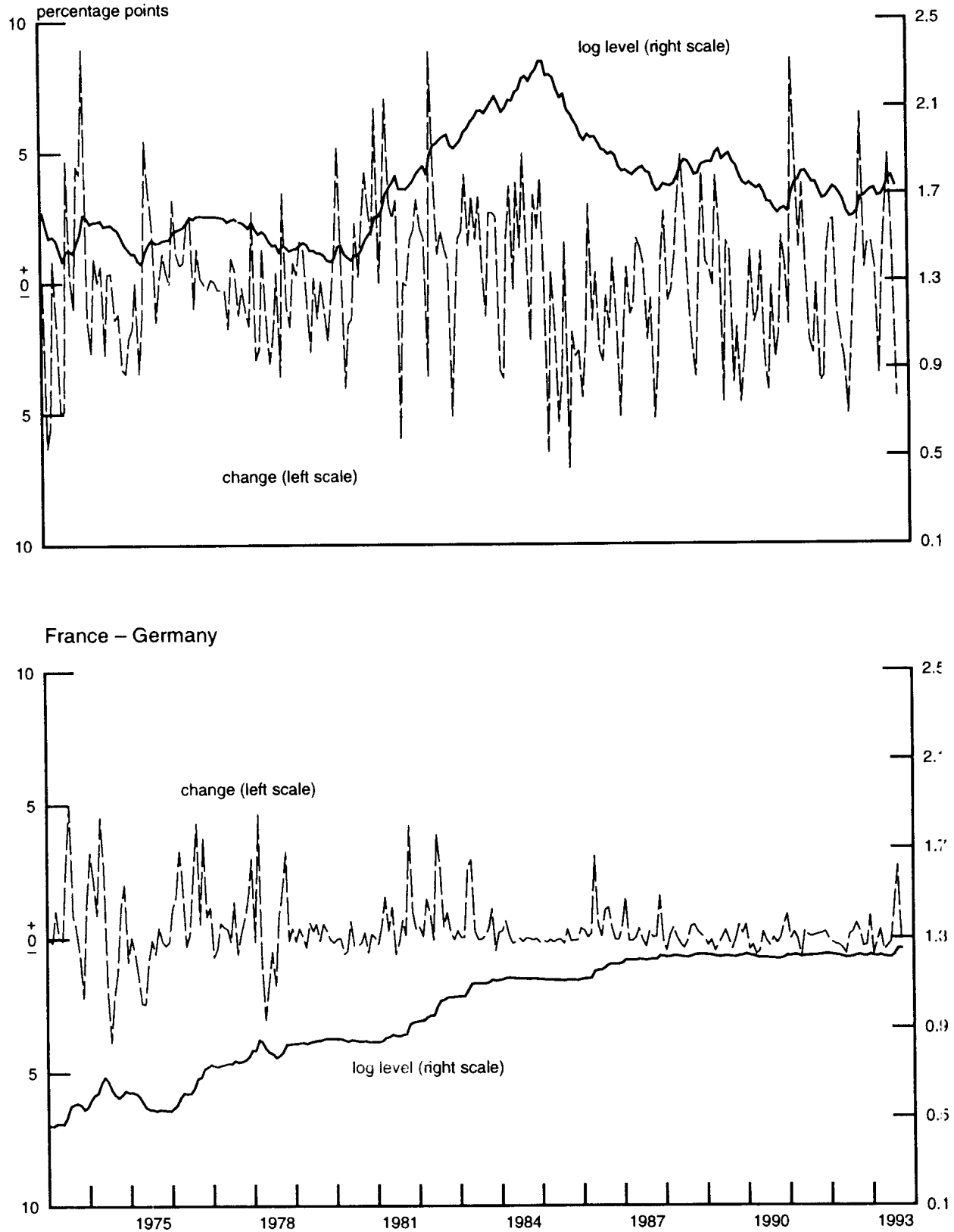
Chart 3

French franc/German mark Exchange Rate

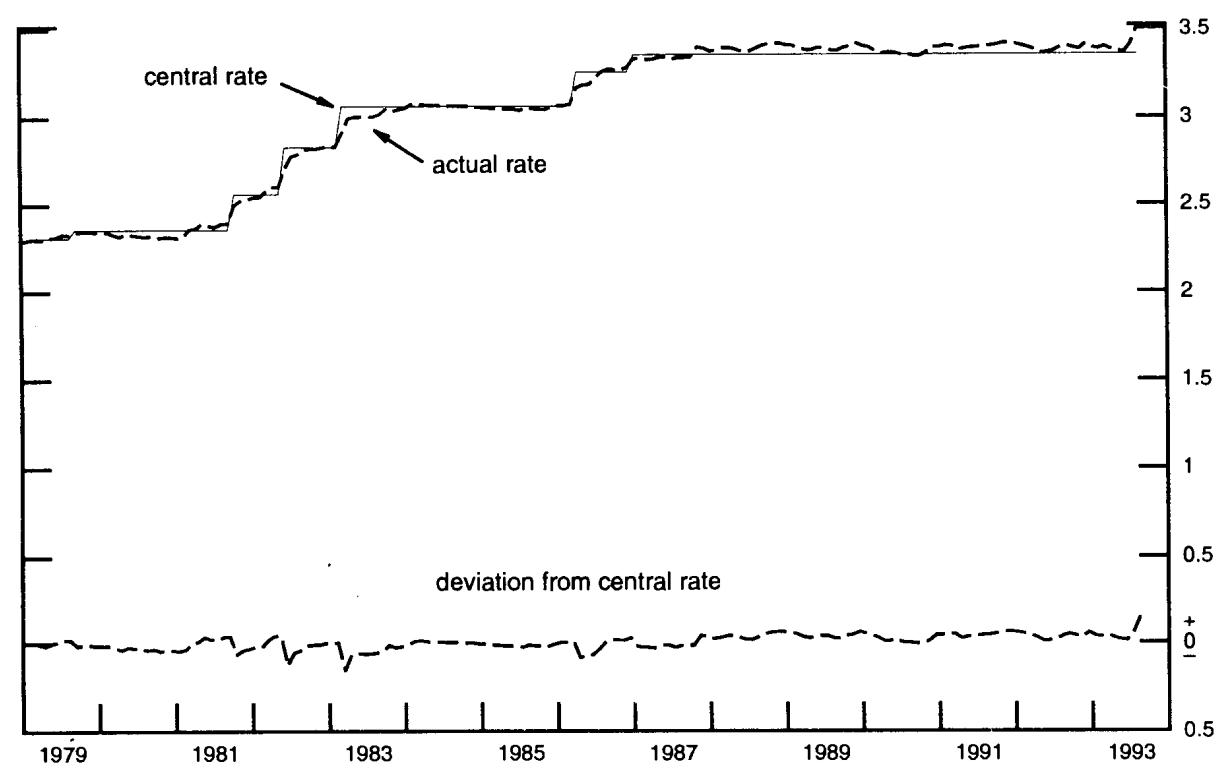


Chart 4

Episodes of Dollar Weakness and Strain in the EMS

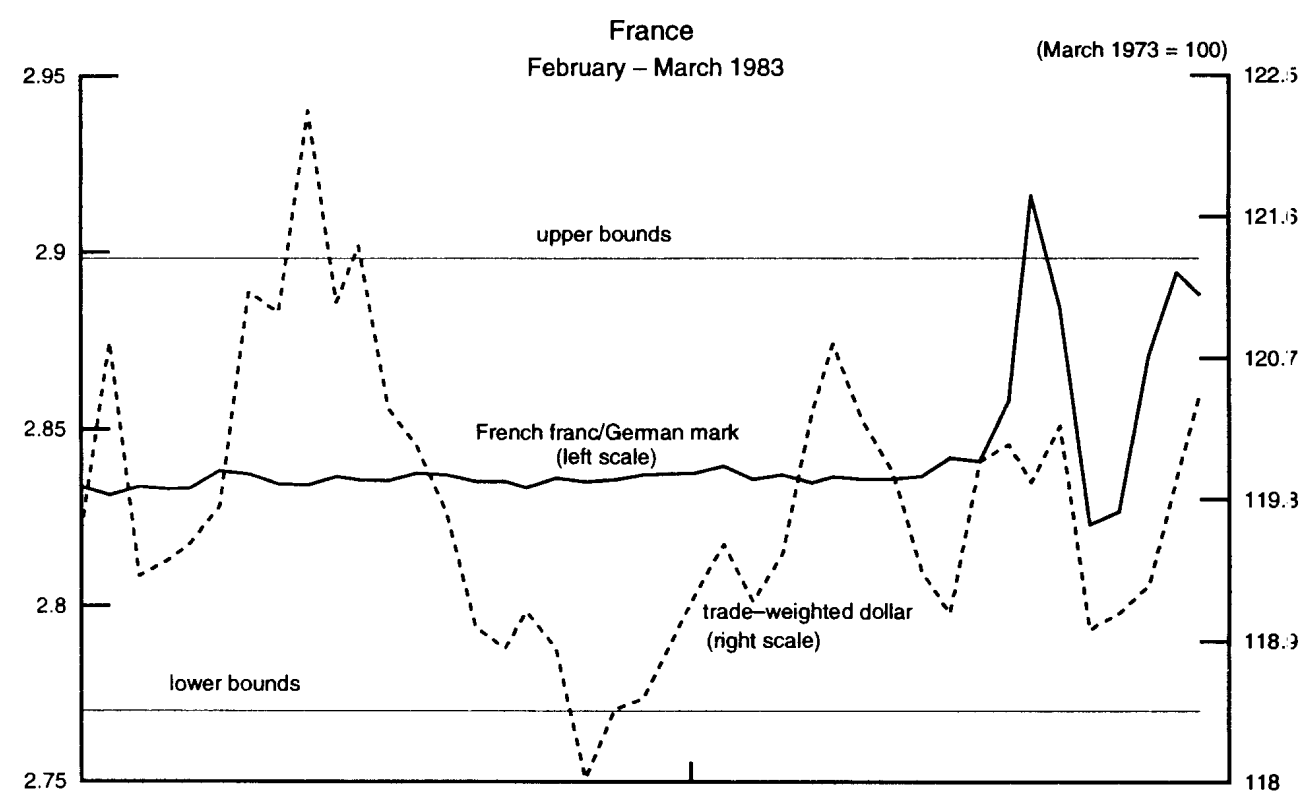

Italy

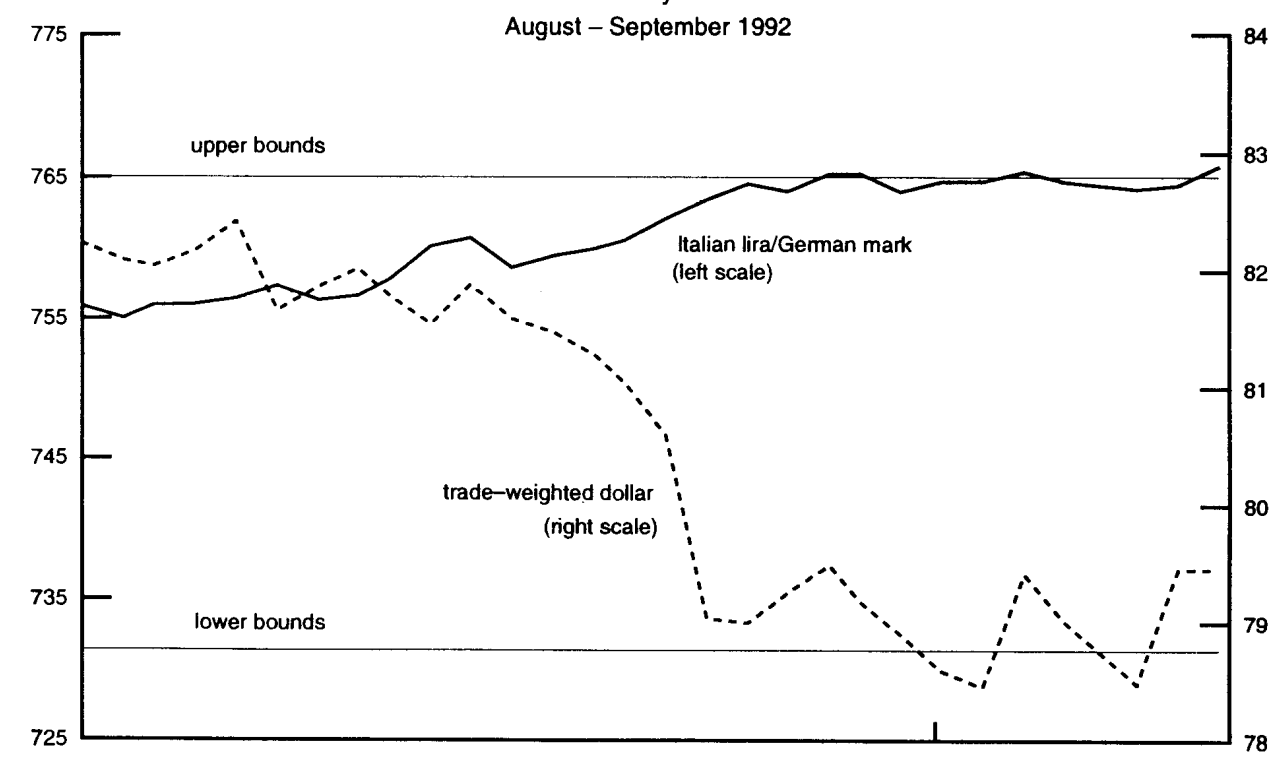


Charts $5-8$
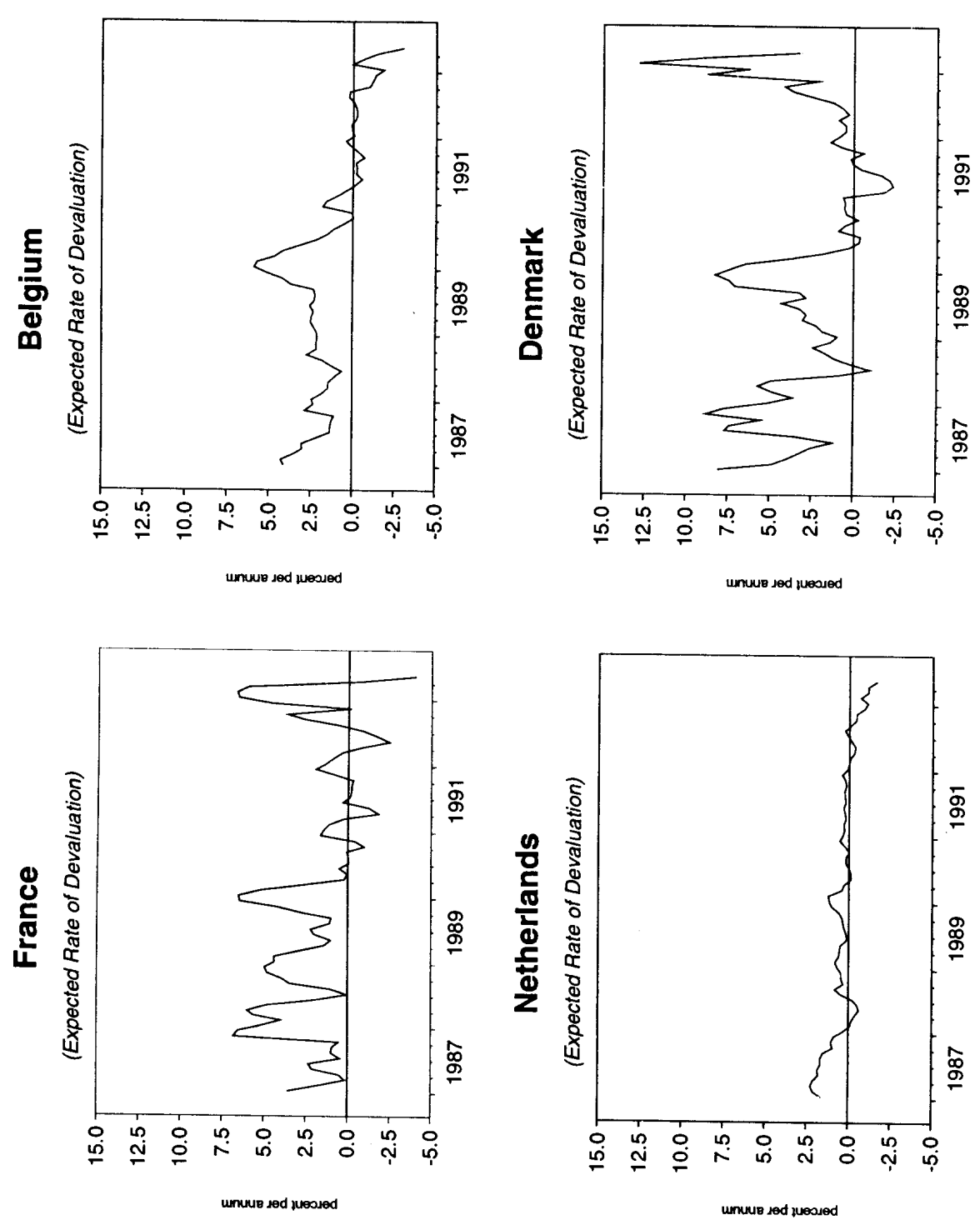
Charts $9-11$
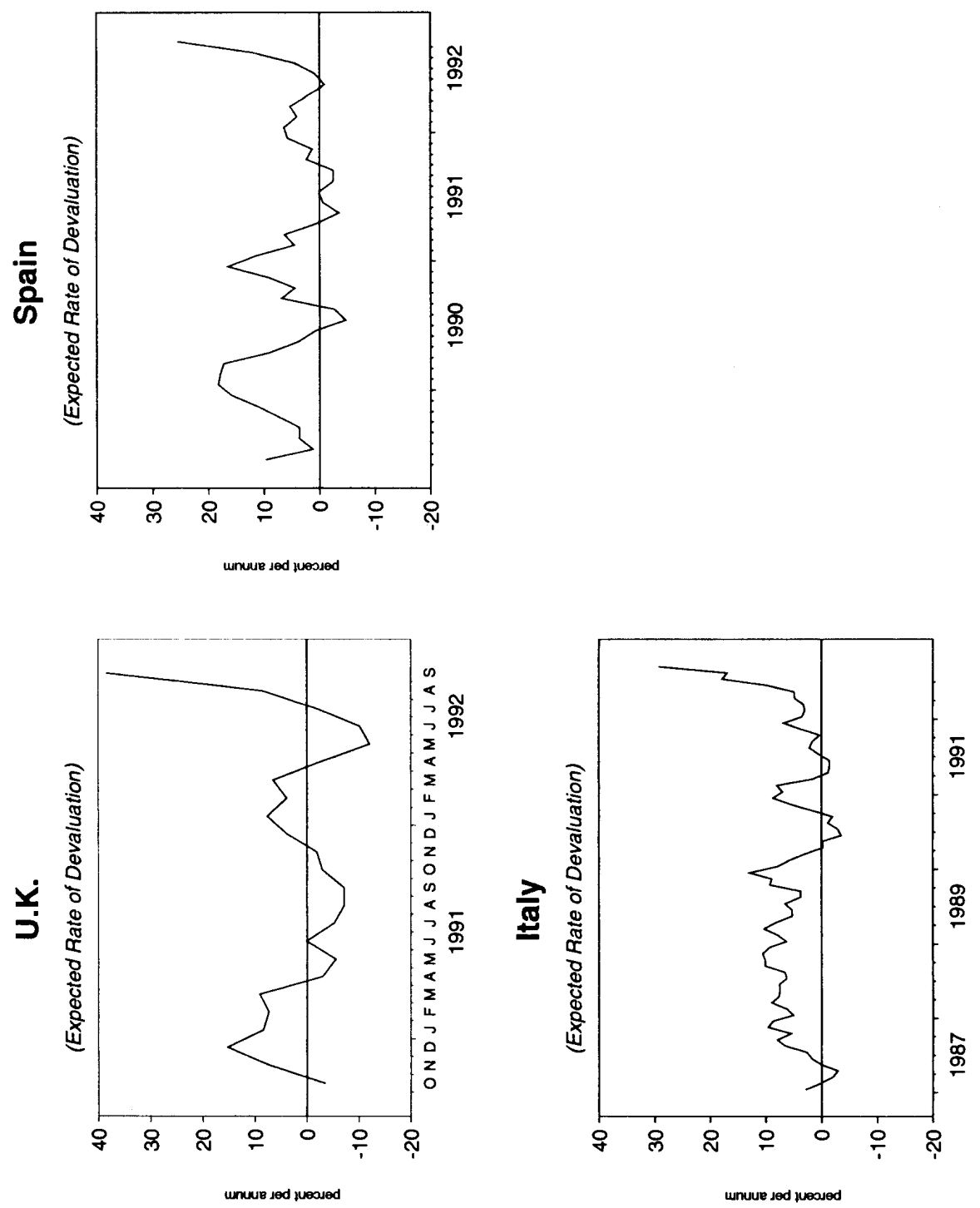


\section{International Finance Discussion Papers}

IFDP

Number

468

467

466

465

464

463

462

461

460

459

458

457

456
Titles

$\underline{1994}$

European Monetary Arrangements: Implications for the Dollar, Exchange Rate Variability and Credibility

Fiscal Policy Coordination and Flexibility Under European Monetary Union: Implications for Macroeconomic Stabilization

The Federal Funds Rate and the Implementation of Monetary Policy: Estimating the Federal Reserve's Reaction Function

Understanding the Empirical Literature on Purchasing Power Parity: The Post-Bretton Woods Era

Inflation, Inflation Risk, and Stock Returns

Are Apparent Productive Spillovers a Figment of Specification Error?

When do long-run identifying restrictions give reliable results?

$\underline{1993}$

Fluctuating Confidence and Stock-Market Returns

Dollarization in Argentina

Union Behavior, Industry Rents, and Optimal Policies

A Comparison of Some Basic Monetary Policy Regimes: Implications of Different Degrees of Instrument Adjustment and Wage Persistence

Cointegration, Seasonality, Encompassing, and the Demand for Money in the United Kingdom

Exchange Rates, Prices, and External Adjustment in the United States and Japan $\underline{\text { Author(s) }}$

Hali J. Edison

Linda S. Kole

Jay H. Bryson

Allan D. Brunner

Hali J. Edison Joseph E. Gagnon William R. Melick

John Ammer

Susanto Basu John S. Fernald

Jon Faust

Eric M. Leeper

Alexander David

Steven B. Kamin

Neil R. Ericsson

Phillip Swagel

Dale W. Henderson

Warwick J. McKibbin

Neil R. Ericsson

David F. Hendry

Hong-Anh Tran

Peter Hooper

Jaime Marquez

Please address requests for copies to International Finance Discussion Papers, Division of International Finance, Stop 24, Board of Governors of the Federal Reserve System, Washington, D.C. 20551. 


\section{International Finance Discussion Papers}

IFDP

Number

455

454

453

452

450

448

447

446

445

444

443

442

441
Titles

1993 Political and Economic Consequences of Alternative
Privatization Strategies

Is There a World Real Interest Rate?

Macroeconomic Stabilization Through Monetary and Fiscal Policy Coordination Implications for Monetary Union

Long-term Banking Relationships in General Equilibrium

The Role of Fiscal Policy in an Incomplete Markets Framework

Internal Funds and the Investment Function

Measuring International Economic Linkage with Stock Data

Macroeconomic Risk and Asset Pricing: Estimating the APT with Observable Factors

Near observational equivalence and unit root processes: formal concepts and implications

Market Share and Exchange Rate Pass-Through in World Automobile Trade

Industry Restructuring and Export Performance: Evidence on the Transition in Hungary

Exchange Rates and Foreign Direct Investment: A Note

Global versus Country-Specific Productivity Shocks and the Current Account

The GATT's Contribution to Economic Recovery in Post-War Western Europe

A Utility Based Comparison of Some Models of Exchange Rate Volatility $\underline{\text { Author(s) }}$

Catherine L. Mann Stefanie Lerway

Derek Utter

Joseph E. Gagnon

Mark D. Unferth

Jay H. Bryson

Michael S. Gibson

Charles P. Thomas

Guy V.G. Sievens

John Ammer

Jianping Mei

John Ammer

Jon Faust

Robert C. Feenstra Joseph E. Gagnon Michael M. Knetter

Valerie J. Chang

Catherine L. Mann

Guy V.G. Stevens

Reuven Glick Kenneth Rogoff

Douglas A. Irwin

Kenneth D. West Hali J. Edison Dongchul Cho 